\title{
A.G.M. of the Hegel Society of Great Britain 1986
}

The Annual General Meeting was held on 11 th September 1986.

Dr. David Lamb and Susan Easton resigned their positions as Secretary/Treasurer and Assistant Secretary/Treasurer and were elected as members of the Council. Dr. Z. Pelczynski was elected Chairman of the Society and Dr. S. Houlgate was elected Secretary/Treasurer. Professor Harris was elected to the post of Honorary President. Professor Petry was elected Chariman of the next Conference and Dr. John Walker elected as Secretary for the next conference. Dr. R. Bernasconi, who had been elected as editor of the Bulletin in 1985 to take over at the end of 1986 , was authorised to appoint two or more assistant editors as required.

It was decided that the Council should draw up a constitution of the Society and present it to the next A.G.M.

Proposals for a joint Anglo-Italian conference were outlined by Dr. Pelczynski. It was agreed that a sub-committee consisting of Professor Pompa, Dr. R. Bellamy, Professor Petry and Dr. Pelczynski should look into the possibility of raising funds for a group of members of the HSGB to attend.

It was agreed that Dr. Lucas, Dr. Pelczynski and Dr. Howard Williams should collaborate with a view to editing and finding a publisher for the 1986 conference papers.

It was decided that the Council should draw up a constitution of the Society and present it to the next A.G.M..

\section{Memorial Plaque for Hegel}

On 14th November 1986 (Hegel's birthday) a plaque commemorating Hegel was unveiled at 48-50 Plöck Building in Heidelberg. This was occasioned by the identification and publication of an official document of 1818 from the Heidelberg town hall. The document was brought to general notice by Katherina Comoth in volume 20 of Hegel-Studien. It bears the following in Hegel's hand: "I shall only be staying here for the next three months. Prof. Hegel." The memorial plaque of black granite carries the inscription: "Georg Wilhelm Hegel lived here between January 1817 and September $1818^{\prime \prime}$. 